\title{
The External and Internal Factors on Small and Medium Enterprise (SMEs) Financing in Islamic Bank
}

\author{
Empirical Evidence From Indonesia
}

\author{
Fira Nurafini \\ Postgraduate School \\ Universitas Airlangga \\ Surabaya, Indonesia \\ firanurafini@gmail.com
}

\author{
Raditya Sukmana \\ Postgraduate School \\ Universitas Airlangga \\ Surabaya, Indonesia \\ momyadit@gmail.com
}

\author{
Sri Herianingrum \\ Postgraduate School \\ Universitas Airlangga \\ Surabaya, Indonesia \\ sriheria@gmail.com
}

\begin{abstract}
The world recognises that micro, small and medium enterprises (SMEs) play a very vital role in developmental and economic growth. This study examines the influence of the external and internal factors on SME financing in Indonesian Islamic banks. The external factors consist of BI Rate and Inflation, while the internal factors consist of SBIS, CAR, ROA, NPF, FDR and ROA ratio on Islamic banking in Indonesia. This study uses quantitative methods. The data used was the monthly data from 2011 to the third quarter of 2016. The data was obtained from Bank Indonesia reports and the Islamic Bank Statistics from the Indonesian Financial Services Authority. The analysis technique used in this research was multiple linear regression. The results from this study are that BI Rate, Inflation, SBIS, CAR, ROA, NPF, FDR and BOPO ratio simultaneously have a significant effect on SME financing in Indonesian Islamic banks from the period 2011 until 2016. Changes in the macroeconomic conditions (external factor) will indirectly have an impact on the internal conditions of Islamic banks, which in turn have an impact on the Islamic banking intermediation function, especially for the SME sector. While partially, only BI Rate, CAR, NPF and FDR ratio have a significant effect on the SME financing of Indonesian Islamic Banks. The other variables, namely Inflation, SBIS, ROA and BOPO ratio, have no significant effect on the SME financing of Indonesian Islamic banks. BI Rate, CAR and NPF ratio have a negative and significant effect on SME financing, while FDR ratio has a positive and significant effect on the SME financing of Indonesian Islamic banks for the period 2011 to 2016.
\end{abstract}

Keywords-Macroeconomics; Monetary Instrument; CAMELS; SME Financing; Islamic Bank

\section{INTRODUCTION}

The world recognises that micro, small and medium enterprises (SMEs) play a very vital role in developmental and economic growth, not only in developing countries but also in developed countries as well. Developed countries like the United States, Japan, France and Netherlands have made the SME sector a trigger of economy in their own country, in ways such as economic growth, innovation and technological progress [23]

The SME sector also has an important role in the economy of a country. According to Tambunan (2008), in Indonesia, SMEs have been the main player in domestic economic activities, especially as a large provider of employment opportunities and hence, they are a generator of primary or secondary sources of income for many households [28]. In 2016, this sector was able to absorb 97.22 percent of the total labour force. This indicates that the SME sector is the major sector of employment in Indonesia, and if this sector is being developed, it could potentially reduce unemployment. In addition to this, the contribution of micro, small and medium enterprises to gross domestic product (GDP) in 2016 has increased from 57.84 percent to 60.34 percent for the last five years.

Banks including Islamic banks have the primary duty of being an intermediary institution, which distributes funds optimally from surplus to those who need the funds. One of the ways of doing this is through financing the SME sector. Giving credit to the business sector, especially the SME sector, needs to be improved in order to increase the role of national banks as an intermediary institution [19]. Banks as a collector and distributor of public funds should be able to manage their credit or finances appropriately so that they can bridge the financial real sector [23].

As an intermediary institution, financing is the main function for Islamic banks, so it needs more attention because the financing can boost economic performance. In financing, there are many factors that affect the bank both internally and externally. Internal factors are factors that come from in the bank itself, while external factors are factors beyond the bank [15].

On the internal side in financing, the bank would need to consider the bank's health because healthy banks are more likely to do their finances well compared with banks that are not healthy. The bank's health can be measured by their 
financial performance contained in their financial statements. Bank Indonesia's Circular Letter No. 9/24 DPbs mentioned that bank health level is influenced by CAMELS such as Capital, Asset Quality, Management, Earnings, Liquidity and Sensitivity. Capital aspects include the Capital Adequacy Ratio (CAR); Asset Aspects include Non Performing Assets Finance (NPF); Earning aspects include Return on Assets (ROA), and Operational Efficiency Ratio (BOPO); and Aspects Liquidity includes Financing to Deposit Liquidity Ratio (FDR).

Alexandri and Santoso (2015), in their study about nonperforming loans, predicted that the occurrence of nonperforming loans can be seen from several factors which include internal factors such as bank size, capital adequacy ratio (CAR) and the operating expenses compared to operating income (ROA) [1]. This means that Islamic bank financing for the SME sector can be also affected by internal factors (CAMELS).

Besides CAMELS, the SBIS instruments that are held by Islamic banks can also affect the amount of SME financing possible by the Islamic bank. SBIS or Bank Indonesia Sharia Certificates is a letter based on sharia principles with a short timed period in rupiah currency issued by Bank Indonesia in order to increase the effectiveness of the monetary mechanisms with sharia principles. As monetary instruments, SBIS has its own transmission lines to the real sector which will affect the amount of financing or lending in the real sector (SMEs). Ramadhan and Beik (2013) investigated the effect of an Islamic monetary instrument (SBIS) towards SME financing in Indonesia. The results showed that there was a significant negative influence of SBIS on SME financing in Indonesia [23]

While on the external side, Islamic banks as financial institutions are naturally influenced by macroeconomic conditions such as inflation and the BI rate, which can also affect the bank's intermediation function, including the financing function for the SME sector. Katmas (2014) examined the effects of inflation, BI rate and exchange rate against Islamic bank financing [15]. The results indicated that inflation and BI Rate has an influence on the volume of financing in Islamic banking, while the exchange rate does not affect the volume of financing in Islamic banking. Additionally, Ibrahim and Sukmana (2011); Kassim et al (2009); Ibrahim and Suffian (2014); Azmi and Ali (2013) found that Islamic bank financing was affected by the changes occurring in relation to the inflation and interest rate policies [4] [11] [12] [14].

In Islamic banking, the financing based on business is divided into two categories, namely the financing of SMEs and non-SMEs [20]. Therefore, from several studies and the explanations above, the researchers intend to examine the influence of internal and external factors on SME Financing in Indonesia Islamic banks.

\section{LITERATURE REVIEW}

\section{A. Islamic Bank}

Accordingly to Islamic Banking Law No. 21/1998 article 1, Islamic banks are banks who run their business based on
Sharia principles and are divided into two types, namely Islamic Banks and Islamic Financing Banks. Islamic principles mean the application of the principles of Islamic law in banking activities based on a fatwa issued by the agency that has the authority in setting the fatwa in the field of sharia. There are some differences between the practices of the Islamic banks with the practices of conventional banks. These differences are explained by the following table:

Table 1. The differences of Islamic Bank and Conventional Bank

\begin{tabular}{|c|c|}
\hline Islamic Bank & Conventional Bank \\
\hline $\begin{array}{c}\text { Halal Investment } \\
\text { lease }\end{array}$ & Halal and Haram Investment \\
\hline Profit and falah oriented & Profit Oriented \\
\hline $\begin{array}{c}\text { Relationships with customers in the } \\
\text { form of a partnership }\end{array}$ & $\begin{array}{c}\text { Relationships with customers in } \\
\text { the form of debtor-creditor } \\
\text { relations }\end{array}$ \\
\hline $\begin{array}{c}\text { Funding and financing should be in } \\
\text { accordance with the Sharia } \\
\text { Supervisory Board fatwa }\end{array}$ & There is no similar councils \\
\hline Source: & \\
\hline
\end{tabular}

Source: [2]

\section{METHOD}

This study analysed the influence of external and internal factors on SME financing in Indonesia Islamic Banks.

- BI Rate is a policy rate reflecting the stance of monetary policy stipulated by Bank Indonesia announced to the public [5]

- Inflation can be interpreted as a tendencies in the increasing prices of goods and services both generally and continuously [27]

- SBIS is a letter paper based on sharia principles with a short timed period in rupiah currency issued by Bank Indonesia in order to increase the effectiveness of the monetary mechanisms with sharia principles [23]

- CAR is the ratio of capital to RWA. RWA consists of RWA for credit risk, operational risk and market risk [20]

- ROA is the ratio of annualised earnings after taxes to the average equity [20]

- NPF is the ratio of credits that are sub-standard, doubtful and losses to total credits [20]

- FDR is the ratio of total financing to the collection of fund and tiers to do with one capital. Total financing is the total financing to third party and other bank [20]

- BOPO is the ratio of operational expenses to operational revenue [20]

The data period for BI rate, inflation, SBIS, CAR, ROA, NPF, FDR and BOPO variable started from the first quarter of 2011 to the second quarter of 2016. The data period for the SME financing started from the second quarter of 2011 to the third quarter of 2016. This difference is because there was time required by the independent variables to affect the dependent variable. In this study, we assumed a three-month 
time lag which means that the changes in macroeconomic variables will affect the SME financing in Islamic banking over three months later. The method used in this research was multiple linear regression. The total data in this study was 66 for each variable. According to Cohen, et al (2007), the larger the sample, the better the study, but there is a minimum amount that must be taken by the researchers which was 30 samples [7]. As stated by Baley in Mahmud (2011), in order to study using statistical data analysis, the minimum sample size that must be taken is 30 samples [17].

\section{FINDING AND DISCUSSION}

Before testing the hypothesis with multiple linear regression, it is necessary to test the classic assumptions first. A classic assumption test is done so then the results of the multiple regression test meet the criteria of Best Linear Unbiased Estimated (BLUE). This classic assumption test consists of a test for normality, multi-colinearity, autocorrelation, and heteroscedasticity. The results from this test are that the regression model in this study has met the assumption of normality, and has no multi-colinearity, autocorrelation and heteroscedasticity.

A multiple linear regression analysis model was used in this study to see the effects of the external and internal factors on SME financing in Indonesian Islamic Banks. The results of the hypothesis test include regression tests simultaneously using an $\mathrm{F}$ test and partially using a t test. Before describing the simultaneous or partially regression results, first we will explain the coefficient of the determination test to see how far the variations in the dependent variable can be explained by the independent variables. The results of the coefficient of the determination test shows that the $\mathrm{R}$ Square value is 0.851 . It shows that $85.1 \%$ of the "SME financing" variance can be explained by changes in the BI rate, inflation, SBIS, CAR, ROA, NPF, FDR and ROA variables. The rest of $14.9 \%$ is explained by other variables outside of the model that have not been considered.

Table 2. Hypothesis Test Result

\begin{tabular}{|l|c|c|}
\hline \multicolumn{1}{|c|}{ Model } & T & Sig. \\
\hline BI Rate & -3.273 & 0.002 \\
\hline Inflation & 1.589 & 0.118 \\
\hline SBIS & 1.262 & 0.212 \\
\hline CAR & -2.251 & 0.028 \\
\hline ROA & -0.089 & 0.930 \\
\hline NPF & -3.580 & 0.001 \\
\hline FDR & 3.762 & 0.000 \\
\hline BOPO & -0.879 & 0.383 \\
\hline
\end{tabular}

An F-test was conducted to see the effect of the independent variable on the dependent variables simultaneously. The results of the $\mathrm{F}$ test showed a significance level of 0.000 . Thus the value is smaller than 0.05 and this means that $\mathrm{H} 1$ is accepted and $\mathrm{H} 0$ is rejected. This suggests that the overall changes in the BI rate, inflation, SBIS, CAR, ROA, NPF, FDR and ROA variable effects the growth of
SME financing significantly. Changes in the macroeconomic conditions (external factors) will indirectly have an impact on the internal conditions of Islamic banking, which in turn will have an impact on the Islamic banking intermediation function when it comes to providing financing, especially for the SME sector.

The t-test was conducted to see the effect of the independents variable on the dependent variable partially. If the significance value is less than the $5 \%$ then this indicates that $\mathrm{H} 0$ is rejected and $\mathrm{H} 1$ is accepted. This means there is a significant effect of an independent variable to the dependent variable. The results of the t test of this study can be explained in the following table:

\section{A. BI Rate influence on SME Financing}

The test results demonstrate that the significance value is 0.002 which is smaller than the significance level (5\%). This means BI rate has a negative significant effect on the the growth of SME financing in the Indonesian Islamic Banks partially. This is in line with Ibrahim and Sukmana's study (2011) which explained that this risk in relation to Islamic bank operating in a dual banking system is seen in the flow of deposit funds and the financing demands swift to and from a conventional bank that occurs following changes in the interest rate [11]. As an example, with an increase in the interest rate, the depositors may anticipate a higher return on their investment deposits. However, Islamic banking may be forced to offer a higher return due to the possibility of losing deposits switching from Islamic banks to conventional banks as they are more likely to raise their deposit rates. So, the increase in conventional bank deposits may decrease the ability of Islamic banks to provide financing, including the financing of the SME sector. Kassim et al (2009) and Ibrahim and Sufian (2014) also found that Islamic bank financing was affected by the changes that occurred in the interest rate policy [12] [14].

\section{B. Inflation influence on SME Financing}

The test results demonstrate that the significance value is 0.118 which means that it is greater than the significance level (5\%). This indicates that $\mathrm{H} 0$ is accepted and $\mathrm{H} 1$ is rejected, so partially, the changes in relation to inflation do not significantly affect the growth of SME financing in Indonesian Islamic Banks. This is not in line with some of the theories and previous research that explained that there was a significant effect from inflation on financing. Figure 1 shows that inflation in the last 5 years is very varied, it contrasts with the changes in SME financing in Indonesian Islamic Banks that are likely to decline in the next two years.

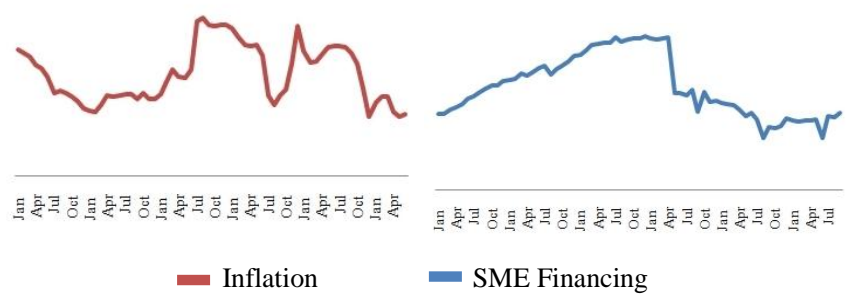

Fig. 1 Inflation and SME Financing Growth in Indonesia Islamic Bank Period 2011-2016 


\section{SBIS influence on SME Financing}

The test results demonstrate that the significance value is 0.212 which is greater than the significance value $(5 \%)$. This indicates that $\mathrm{HO}$ is accepted and $\mathrm{H} 1$ is rejected, so partially, SBIS has no significant effect on the growth of SME financing in Indonesian Islamic Banks. This is in contrast with the results of Ramadan and Beik (2013) who explained that there was a negative relationship between bonus SBIS and SME financing. This difference could be due to the different sources of data used. In Ramadan and Beik's (2013) study, the SBIS variable is described by the bonus rate, whereas SBIS in this study is described by the volume of SBIS owned by Indonesian Islamic banks [23]. In addition, Figure 2 below shows that the volume of SBIS in the last five years tends to be stable while the financing of SME tend to decrease.

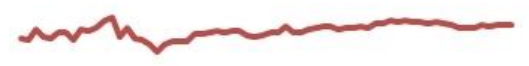

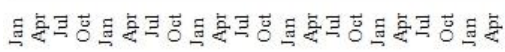

Fig. 2 The Growth of SBIS Period 2011-2016

\section{CAR influence on SME Financing}

The test results demonstrate that the significant value is 0.028 which is smaller than the $5 \%$ significance level. It indicates that $\mathrm{H} 0$ is rejected and $\mathrm{H} 1$ is accepted, so partially, CAR has a negative and significant effect on the growth of SME financing in Indonesian Islamic Banks. This is in line with Katmas (2014) who explained that if the CAR ratio increases, then the capital owned by banks is used more to protect the bank's assets that contain risks [15]. This means that the capital used for financing will be reduced. In Islamic banking, financing based on business is divided into two categories, namely the financing of SMEs and non-SMEs (20). Therefore, CAR also has a negative and significant effect on SME financing.

\section{E. ROA influence on SME Financing}

The test results demonstrate that the significant value is 0.930 which is greater than the significance level $(5 \%)$. It indicates that $\mathrm{H} 0$ is accepted and $\mathrm{H} 1$ is rejected, so partially, ROA has no significant effect towards the growth of SME financing in the Indonesian Islamic Banks. This is not in line with some of the theories and previous research that has explained that there was a significant influence of ROA on bank credit and financing. Figure 3 shows that the growth of ROA is not in line with the growth of SME financing in Indonesian Islamic Banks. Around the period of 2011-2013 when ROA was quite volatile, SME financing tended to increase.

\section{F. FDR influence on SME Financing}

The test results demonstrate that the significant value is 0,000 which is smaller than the significance level (5\%). This indicates that $\mathrm{H} 0$ is rejected and $\mathrm{H} 1$ is accepted, so partially,
FDR variable has a positive and significant effect on the growth of SME financing in Indonesian Islamic Banks. This is in accordance with Katmas (2014) who explained that the higher the FDR ratio of the bank, the better the bank is in the intermediary function. The higher the financing is, the higher the FDR. Vice versa, if the financing is declining then the FDR will also decrease, so FDR has also a positive influence on financing (22). In Islamic banking, the financing based on business is divided into two categories, namely the financing of SMEs and non-SMEs (20). Therefore, FDR also has a positive and significant effect on SME financing.

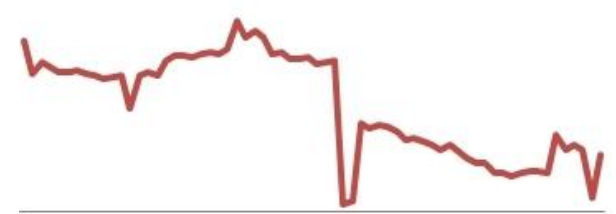

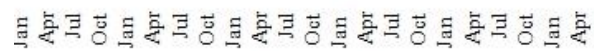

Fig. 3 The Change of ROA ratio Period 2011-2016

\section{G. BOPO influence on SME Financing}

The test results demonstrate that the significant value is 0.383 which is greater than the significance level $(5 \%)$. This indicates that $\mathrm{HO}$ is accepted and $\mathrm{H} 1$ is rejected, so partially, BOPO has no significant effect on the growth of SME financing in Indonesian Islamic Banks. This is not in line with the theory that is described by Katmas (2014) who explained that there is a [15] negative correlation between the BOPO ratio and financing. The higher the $\mathrm{BOPO}$, the lower the financing provided. From Figure 7, we can see that the growth of BOPO is not in line with the growth of SME financing in Indonesian Islamic Banks. Around the period of 2011 to 2013, BOPO conditions tend to be stable while SME financing tend to increase quite highly.

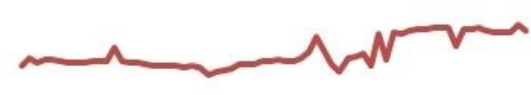

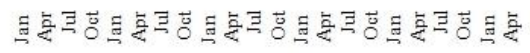

Fig. 4 The Change of BOPO ratio Period 2011-2016

\section{CONCLUSIONS}

The external and internal factors affect the volume of SME financing extended by Islamic banking in Indonesia simultaneously. While partially, only BI Rate, CAR, NPF and the FDR Ratio has a significant effect on SME financing, when extended by Islamic banking in Indonesia. Changes in the macroeconomic conditions (external factors) will indirectly have an impact on the internal conditions of Islamic banking, which in turn have an impact on the Islamic banking intermediation function, namely the financing function and especially in the SME sector. Therefore, external and internal factors can simultaneously affect the volume of SME financing in relation to Islamic banking in Indonesia. The variables of BI Rate, CAR, and NPF have a negative and 
significant effect, while the variable of FDR has a positive and significant effect towards SME financing by the Islamic banks in Indonesia. Meanwhile the other variables, namely inflation, SBIS, ROA and the BOPO ratio, does not significantly affect SME financing extended by the Islamic banking system in Indonesia for the period 2011 to 2016.

\section{References}

[1] Alexandri, Moh Benny and Teguh Iman Santoso. Non Performing Loan: Impact of Internal and External Factor (Evidence in Indonesia). International Journal of Humanities and Social Science Invention. 4(1), 2015.

[2] Antonio, Muhammad Syafi'i. Islamic Bank: from Theory to Practice. Jakarta: Gema Insani (in Indonesian), 2001

[3] Arianti, Wuri Novi. The analysis of DPK, CAR, NPF and ROA influences on Islamic Banking Financing (Study Case on Indonesia Muamalat Bank Period 20012011). Diponegoro Journal Of Management, 2(1). (In Indonesian), 2012

[4] Azmi, Choudhary Wajahat Naeem and Mohsin Ali. Impact of Inflation on Islamic Financing: Empirical Evidence from Malaysia. ISRA Internation Journal of Islamic Finance. 5 (2), 2013.

[5] Bank Indonesia. Data of BI Rate. Retrieved from http://www.bi.go.id/id/moneter/bi-rate/data/, 2017

[6] Bank Indonesia. Data of Inflation. Retrieved from http://www.bi.go.id/id/moneter/inflasi/data/, 2017

[7] Cohen, L., et al. Research Methods in Education $\left(6^{\text {th }}\right.$ Ed). New York: Routledge, 2007.

[8] Dendhawijaya, Lukman. Bank Managemet ( $2^{\text {nd }}$ Ed). Jakarta, Indonesia: Ghalia Indonesia. (in Indonesian), 2003

[9] Ghozali, L. The Application of Multivariate Analysis with SPPS. Semarang, Indonesia: Publisher Institution of Diponegoro University. (In Indonesian), 2006

[10] Gujarati, D. The Basic of Econometric. Jakarta, Indonesia: Erlangga (In Indonesian), 1978

[11] Ibrahim, MH and Raditya Sukmana. Dynamics of Islamic Financing in Malaysia: Causality and Innovation Accounting: Journal of Asia-Pasific Business Journal of Asia Pasific Business. 12(1), 2011.

[12] Ibrahim, MH and Fadzlan Sufian. A Structural VAR analysis of Islamic Financing in Malaysia. Studies in Economics and Finance. 31 (4), 2014.

[13] Karim, Adiwarman. Islamic Bank: Fiqh and Finance Analysis. Jakarta, Indonesia: PT Raja Grafindo Persada. (In Indonesian), 2007

[14] Kassim, SH and M. Shabri Abd Majid. Impact of Financial Shocks on Islamic Banks. International Journal of Islamic and Middle Eastern Finance and Management. 3 (4), 2010.
[15] Katmas, Ekarina. The Influence of External and Internal Factors on Financing Volume in Indonesia Islamic Bank (Bachelor's Thesis), UIN Syarif Hidayatullah, Jakarta, Indonesia. Retrieved from http://repository.uinjkt.ac.id/ (In Indonesian), 2014

[16] Kuncoro dan Suhardjono. Bank Management: Theory and Application ( $\left.1^{\text {st }} \mathrm{Ed}\right)$. Yogyakarta, Indonesia: BPFE. (In Indonesian), 2002

[17] Mahmud. Education Research Method. Bandung, Indonesia: Pustaka Setia. (In Indonesian), 2011

[18] Maula, Khodijah Hadiyyatul. The Influence of DPK, Self Capital, Proft Margin and NPF on Murabahah Financing in Mandiri Sharia Bank (Bachelor's Thesis), UIN Sunan Kalijaga Yogyakarta, Indonesia. Retrieved from http://digilib.uin-suka.ac.id/ (In Indonesian), 2009

[19] Meydianawathi, L.H. The Analysis of Bank Credit Bergaining Behaviour on SME Sector in Indonesia (Period 2002-2006). Economy Study Bulletin, 12(2). (In Indonesian), 2007

[20] Otoritas Jasa Keuangan. Islamic Bank Statistic. Retrieved from www.ojk.go.id/id/kanal/syariah/datadan-statistik/statistik-perbankan-syariah, 2011 - 2016

[21] Prastowo, Dwi. Financial Report Analysis: The Concept and Application ( $3^{\text {rd }}$ Ed). Yogyakarta, Indonesia: UPP STIM YKPN. (In Indonesian), 2011

[22] Rachman, Yoga Tantular. The Influence of FDR, NPF, ROA, CAR on Mudharabah Financing, Strengthing Islamic Economics and Financial Institution for the Welfare of Ummah, Proceedings of ICIEF'15, Mataram, Indonesia. Retrieved from http://repository.widyatama.ac.id/ (In Indonesian), 2015

[23] Ramadhan, MM \& IS Beik. The Analysis of Islamic and Conventional Moneter Instrument Influence on SME Financing in Indonesia. Al-Muzara'ah Journal, 1(2). (In Indonesian), 2013

[24] Subramanyam et al. Financial Report Analysis. Jakarta, Indonesia: Salemba Empat. (In Indonesian), 2013

[25] Sukirno, Sadono. The Introduction of Macroeconomic Theory. Jakarta, Indonesia PT Raja Grafindo Persada. (In Indonesian), 2004

[26] Susanti, Luh Rahmi. The Analysis of Macroeconomics Influence on Credit Growth in Indonesia Bank Period 2002-2009 (Bachelor's Thesis), Indonesia University, Jakarta, Indonesia. Retrieved from http://lib.ui.ac.id/ (In Indonesian), 2010

[27] Suseno and Siti Astiyah. Inflation. Pusat Pendidikan dan Studi Kebanksentralan: Jakarta. (In Indonesian), 2009

[28] Tambunan. SME Development, economic growth and government intervvention in a developing country: the indonesian story. J Int Entrepr. 6(147-167), 2008.

[29] Uyanto, Stanislaus, S. The Guide of Data Analyze with SPSS. Yogyakarta, Indonesia: Graha Ilmu. (In Indonesian), 2009 